\title{
Tracheal suture in rats with hypothyroidism. Wound healing study ${ }^{1}$
}

\author{
Traqueorrafia em ratos com hipotireoidismo. Estudo da cicatrização
}

\author{
Elise Zimmermann", Jurandir Marcondes Ribas-Filho", Osvaldo Malafaia", Carmen Austrália Paredes Marcondes Ribas", \\ Paulo Afonso Nunes Nassif ${ }^{\text {II }}$ Edmar Stieven Filho ${ }^{\text {III }}$, Paulo Eduardo Przysiezny ${ }^{\text {IV }}$ \\ ${ }^{I}$ Master, Principles of Surgery Post-Graduate Program, Evangelical Medical School, Curitiba - PR, Brazil. \\ II PhD, Full Professor, Post-Graduate Program, Evangelical Medical School, Curitiba - PR, Brazil. \\ ${ }^{\text {III }}$ Master, Post-Graduate Program, Evangelical Medical School, Curitiba - PR, Brazil. \\ IV Master, Buccomaxilofacial Surgery, Marilia University, Marilia -SP, Brazil.
}

\begin{abstract}
Purpose: To evaluate the influence of hypothyroidism in tracheal wound healing process. Methods: A controlled study was designed with 48 male Wistar rats, divided into two groups: study and control groups. In the first one hypothyroidism was surgically induced and 10 weeks after, a tracheal opening followed by suture was performed in both groups, subdivided into 7, 14, and 21 days in accordance with the date of animals death. A laboratorial evaluation was performed to prove the decreased in thyroid function in the study group. Also a macroscopic evaluation through a stablished protocol and a microscopic analysis with Hematoxylin-eosin and Sirius-Red staining methods were done. Results: The laboratorial evaluation certified suppressed thyroid function in the study group. The macroscopic evaluation showed the presence of suture blockade in the study group in all the evaluated days. Microscopic analysis showed a prolongated inflammatory process and less collagen with delay in organization in the study group comparing to control group. All these data were statistic significant. Conclusion: Hypothyroidism had an influence in tracheal wound healing process, promoting delay in the inflammatory and organization processes and diminished tissue collagen quantity.
\end{abstract}

Key words: Wound Healing. Hypothyroidism. Trachea. Rats.

\section{RESUMO}

Objetivo: Investigar a influência que o hipotireoidismo exerce no processo cicatricial da traquéia. Métodos: Estudo controlado, com 48 ratos Wistar machos, divididos em dois grupos, denominados: grupo estudo e grupo controle. No primeiro induziu-se hipotireoidismo cirurgicamente e após 10 semanas, realizou-se nos dois grupos o procedimento de abertura traqueal seguida de sutura. Houve subdivisão destes grupos em 7, 14 e 21 dias, de acordo com a data de morte dos animais. Foi realizada avaliação laboratorial para comprovar o hipotireoidismo no grupo estudo, avaliação macroscópica e microscópica através das colorações de hematoxilina-eosina e Sirius Red. Resultados: A avaliação laboratorial atestou que o grupo estudo encontrava-se em estado de hipotireoidismo. A avaliação macroscópica demonstrou predomínio de bloqueio da sutura no grupo estudo em todos os momentos avaliados. A microscopia comprovou prolongamento da fase inflamatória e diminuição da quantidade total de colágeno bem como atraso na sua organização no grupo estudo em relação ao grupo controle. Todos estes dados apresentaram significância estatística. Conclusão: O hipotireoidismo influencia no processo de cicatrização traqueal prolongando a fase inflamatória, diminuindo a quantidade de colágeno e atrasando sua maturação e organização. Descritores: Cicatrização de Feridas. Hipotireoidismo. Traquéia. Ratos.

${ }^{1}$ Research performed at Principles of Surgery, Post-Graduate Program, Evangelical Medical School, Curitiba - PR, Brazil.

\section{Introduction}

Wound healing is a dynamic process that usually starts after tissue wound. It alternates anabolic and catabolic reactions administered by a great variety of cellular and molecular events that interact among themselves in order to start the wound healing process.

For didactic purposes, this reparation process may present three distinct superposed stages named: inflammatory stage, proliferative stage, and remodeling of the matrix formation stage. The retardation or failure in one of these stages may slow down or even hinder the process of wound healing. However, from the clinical point of view, the formation and matrix remodeling stage is the most important stage $e^{1,2}$.

From the functional point of view, no matter what kind of tissue lesion, collagen is the most important component of tissue cicatrization. It is the standard, the quality and total quantity of collagen in the matrix that determine the resistance of the scar. In the course of cicatrization, these collagen fibers get thicker, ranging along the power lines of the wound in the process of remodeling and maturation, offering more resistance to the cicatricial tension ${ }^{3}$. 
Alterations in the cicatricial process have been described in patients who presented hypothyroidism gravis, resulting from total thyroidectomy or from cervical radiotherapy ${ }^{4,5}$.

Thyroid hormones have an important role in the growth and development of organs and tissues, essential to the maintenance of life quality ${ }^{6}$.

The hypofunction of the thyroid gland increases the chances of pre and post operatory complications ${ }^{7,8}$.

Thyroid hormones are associated with the proliferation and secretion of fibroblasts. The suppression of this hormone secretion disturbs the metabolic activation in tissues the in the collagen synthesis, extending from the inflammatory stage to the proliferative stage ${ }^{9}$.

The cicatrization process requires proteins and energy sources and it has been proved that the administration of thyroid hormone to animals suffering from hypothyroidism induced the synthesis of nucleic acid and proteins, besides increasing mitochondrial oxidative phosphorylation ${ }^{10}$. Studies with hypothyroid rats demonstrated that there is a compromise in the collagen synthesis decreasing its biosynthesis, collagen concentration, delaying its organization, solubility and metabolism ${ }^{11}$.

Tracheotomy is one of the most common surgical procedures performed on critical patients.

ICUs (Intensive Care Units) present a rate of complication that varies from 4 to $40 \%$. Tracheal or sub-glottal stenosis is still a controversial subject and only a few studies present factors that could interfere in the answer to proposed theraphies ${ }^{12,13}$.

This work aims at studying the effect of hypothyroidism on tracheal tissue cicatrization in rats.

\section{Methods}

This study was performed according to the Brazilian Law on experiments with animals and the normative document of the Brazilian College of Animal Experimentation. The experiment was approved by the Ethics Committee in Animal Research of the Institution.Forty eight male Wistar rats (Rattus norgegicus albinus, Rodentia mammalia) aged between 100 and 130 days, weighing between 288 and 444 grams, coming from the Animal House of the Technology Institute of Paraná were used in this study. They were kept in polypropylene boxes under constant temperature of $20+-2{ }^{\circ} \mathrm{C}$, at room humidity, with light cycles each 12 hours. The animals had free access to water and standard lab rat food. The animals in the study group, after undergoing thyroid and parathyroidectomy, were fed with pentahydrated calcium lactate at $2 \%$ and water ad libitum.

The animals were identified with picric acid and divided in groups A (Control) and B (Study). Group A animals were submitted to simulate cervicotomy with digital manipulation of the thyroid gland, while Group B animals underwent thyroid parathyroidectomy.

Ten weeks after the surgical procedures, all the animals were submitted to tracheotomy and tracheal suture between the third and fourth tracheal rings. Animals in groups A and B were divided in six subgroups of eight animals denominated groups A1, A2, A3 and B1, B2, B3 to be euthanized, respectively after 7, 14 and 21 days after the tracheal procedure. The tracheal opening was performed under direct visualization, with the help of a surgical magnifying glass. A transversal incision, shorter than the tracheal diameter was made. Afterwards, a tracheal suture with separate 25 poliglecaprone stitches was made, followed by the approximation of the muscular plane with 4.0 poliglactina thread, the skin and subcutaneous tissue synthesis, with 4.0 nylon monofilament thread (Figure 1).

After the surgical procedures, the animals were kept in individual cages in a heated room until they were completely recovered from anesthesia.

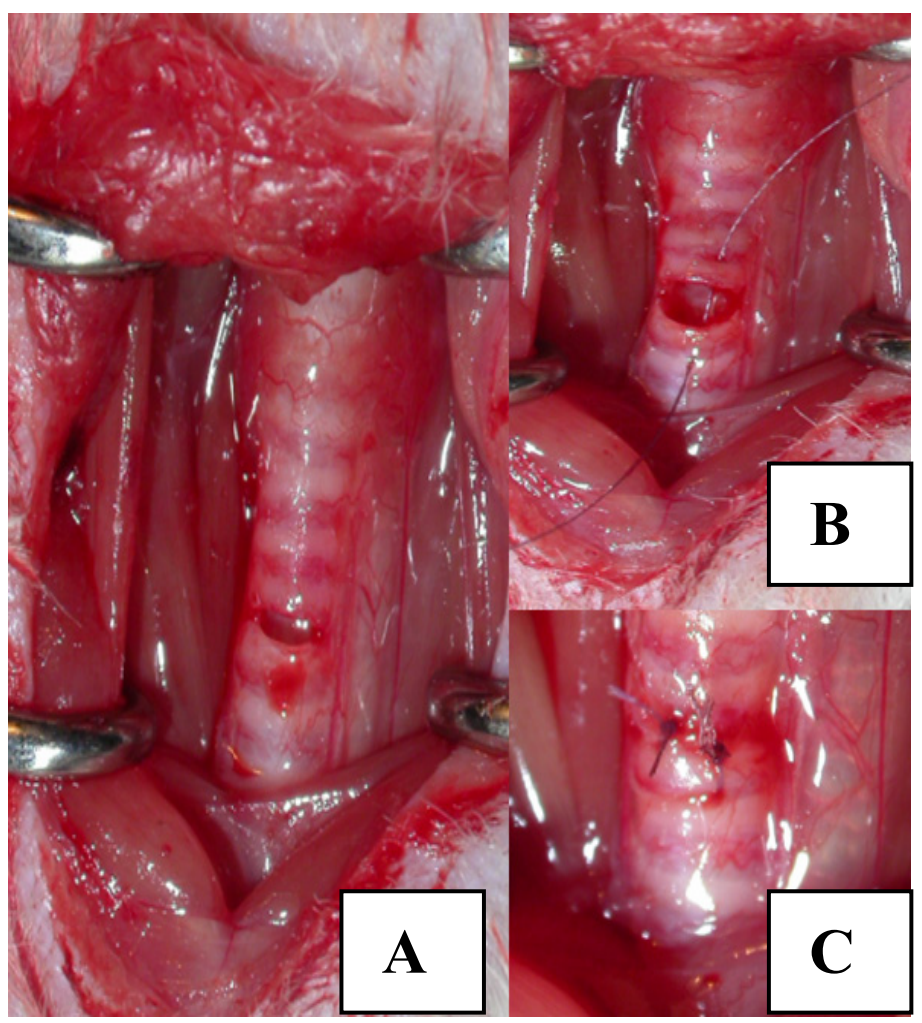

FIGURE 1 - Tracheotomy followed by tracheal suture: A. Shows the inter-cartilaginous opening of the trachea; $\mathbf{B}$. Shows the suture thread on the incision; C. Tracheal suture with separate stitches

After each surgical procedure, $40 \mathrm{mg} / \mathrm{mL}$ per $2 \mathrm{mg} / \mathrm{kg}$ weight paracetamol was used as analgesic.

For euthanasia, the rats were placed in a closed bell jar for the inhalation of $97 \%$ sulfuric ether lethal vapor. At the moment of the animals' death, a cardiac puncture with a $25 \mathrm{X} 7$ needle was made, withdrawing $3 \mathrm{~mL}$ of blood in order to measure TSH ultra-sensitive, total thyroxine and ionized calcium (ion selective electrode method), taking as reference values the results of the control group analyses.

For the macroscopic investigation not only the presence of adherences but also the presence of abscesses, dehiscence and fistulas were considered. The clinical findings were transformed in numerical parameters. For the tracheal wound 0 (zero) was established, if it presented good healing (cicatrized wound without dehiscence); 1 (one) for doubtful healing (presence of abscess) and 2 for the presence of dehiscence, if it occurred and 1 (one) if it didn't occur. It was also established 0 (zero) for the absence of fistulas and 1 (one) for the presence of fistulas. 
After macroscopic evaluation, the entire trachea was carefully resected up to the carina. Specimens were kept in flasks containing $10 \%$ formaldehyde solution for at least 24 hours and then they were prepared for the histological study. They were kept in paraffin blocks and 4 micrometers thick histological cuts were made which were stained with Hematoxylin-eosin and Sirius-red. These samples were labeled with specific codes, known only to the team who performed the surgical procedure.

The histological cuts stained with Hematoxylin-eosin were intended to the evaluation of the type and intensity of the inflammatory reaction in the presence of fibrin leukocytic scab (fibrin and blood cells on the surface of the wound, clot dehydration); angiofibroblastic proliferation (granulate tissue formation, of the neo-vascularization and proliferation of fiberblasts); edge re-epithelization (moving of the epithelium over the wound); foreign body reaction (granulomatous aggregation with giant cells around the suture thread and the presence of microphages); micro-abscess (tissue necrosis in the presence of neutrophils and macrophages). These parameters were classified according to their intensity: absent, discrete and moderate and were scored in order to be transformed in quantitative variables.

For the evaluation of the area, density and quantification of types I and III collagens, the histological cuts were stained with Sirius-red. Samples were analyzed using the Image Pro Plus Application, connected to a Sony video camera and a BX 50 microscope, at magnification of 200 , taking into consideration not only the total area (in micra) but also the collagen types I and III percentages. The thicker and strongly birefringent fibers were stained orange and red (type I) and the thinner and less birefringent fibers were stained yellow and green (type III). An average of these percentages was obtained in each slide and the total collagen value corresponded to the sum of the red and green areas.

Two distinct cuts (inferior and superior) 200 times augmented were analyzed and the best resolution of each polarized image with Olympus U-Pot lens, turned anti clock wise until polarization was selected. The representative values of the area (in micra) and of collagen I and III percentage were transported to Microsoft ${ }^{\circledR}$ Excel for statistical analysis.

Comparing control and study groups, in relation to the quantitative variables, Student's t test was used for independent samples, taking into consideration the evaluation of the homogeneity of the variables. In relation to the nominal dichotomous variables, the groups were compared using Fisher's exact test. The variables' normality condition was evaluated using the Shapiro-Wilks test. Values from $\mathrm{P}<0,05$ were statistically significant.

\section{Results}

\section{Laboratorial evaluation}

The ultrasensitive TSH dosage in Group I presented values that varied between 38,47 e $51,03 \mu \mathrm{UI} / \mathrm{mL}$, and the control group presented values between 1,75 and 2,02 $\mu \mathrm{UI} / \mathrm{mL}$ (Figure 2).

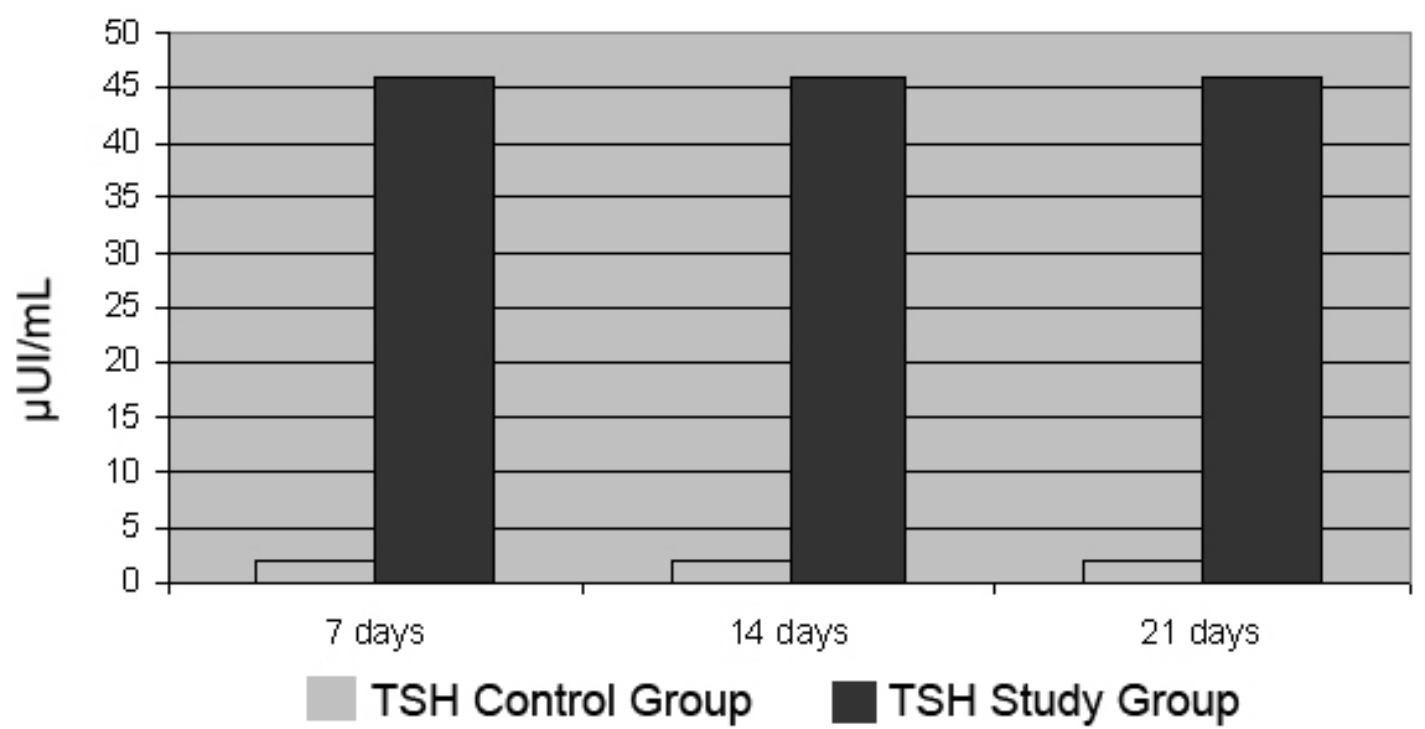

FIGURE 2 - Results of TSH dosage in all 48 animals 
Total thyroxin evaluation (T4) analyzed, using the same method, varied in the study group between 0,29 and $0,43 \mathrm{mg} / \mathrm{dL}$ and in the control group between 2, 50 and 3,70mg/dL (Figure 3).

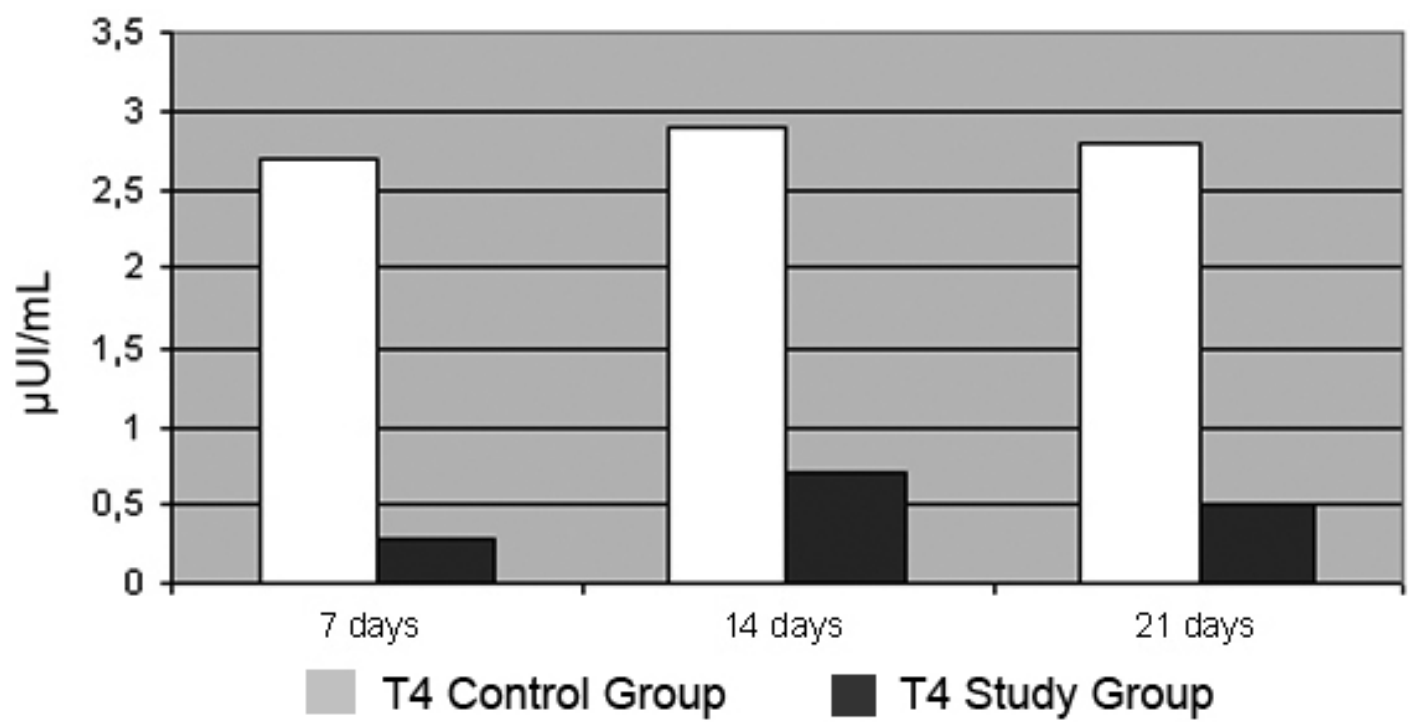

FIGURE 3 - Results of T4 dosages in all 48 animals

The values of ionic calcium evaluation in the Study Group varied between 0, 86 and 1,02 mmoI/L and in the Control Group between 0,94 and $1,15 \mathrm{mmol} / \mathrm{L}$.

The Study Group presented TSH levels above those of the reference values and T4 bellow them. The control Group maintained itself within normality. There was no significant difference between both groups in relation to ionic calcium values which proves hypothyroidism in the Study group and indicates that the calcium reposition was effective in this group.

\section{Macroscopic evaluation}

Considering wound and fistula variables, the macroscopic evaluation showed no significant statistical difference between both groups.

As to the blockade variable, it predominated in the Study Group during death, presenting statistically significant differences with $\mathrm{P}<0,05$ (Figure 4).

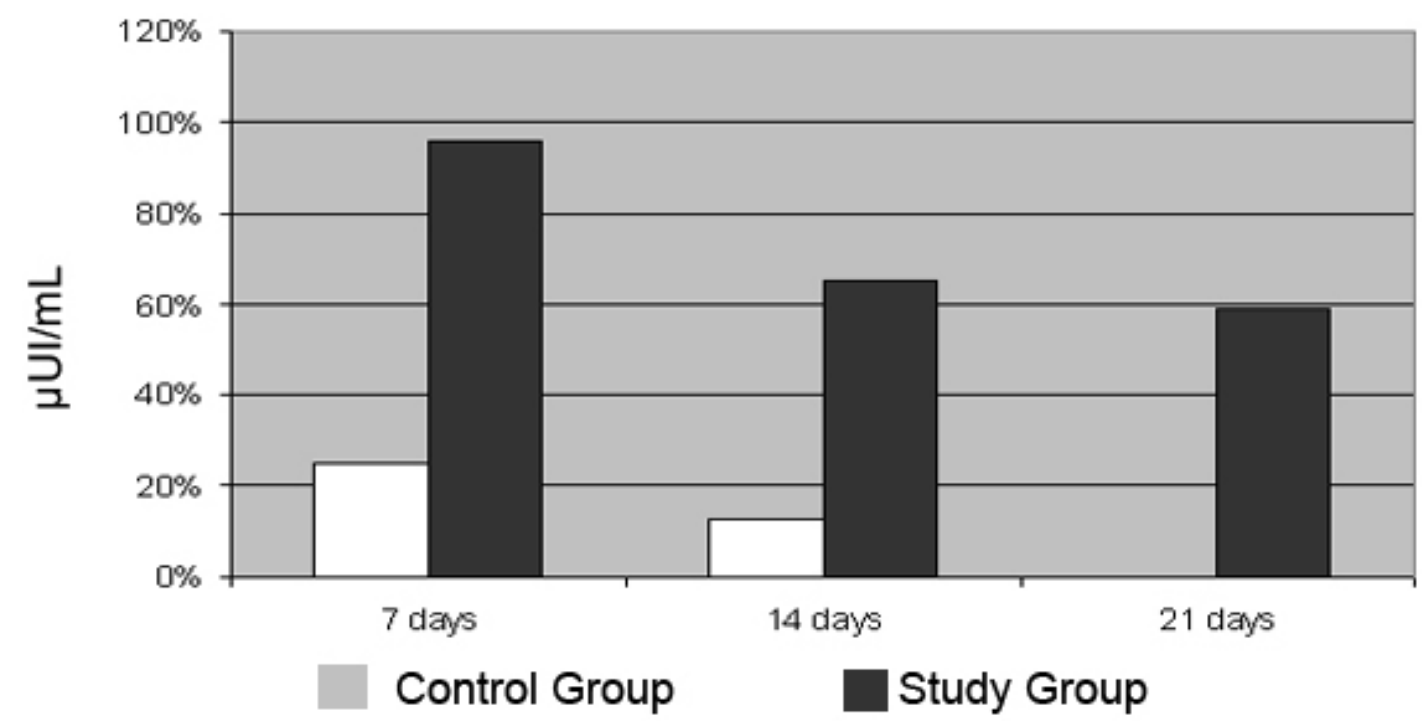

FIGURE 4 - Presence of Blockade in the suture 
Microscopic evaluation

Evaluation considering Hematoxilin-eosin coloration
Considering the analyzed variables, the proliferation of fibrine and leukocytes predominated in the study group at the 14th day of evaluation with $\mathrm{P}=0,01$ (Figure 5). The other variables did not present statistically significant difference.

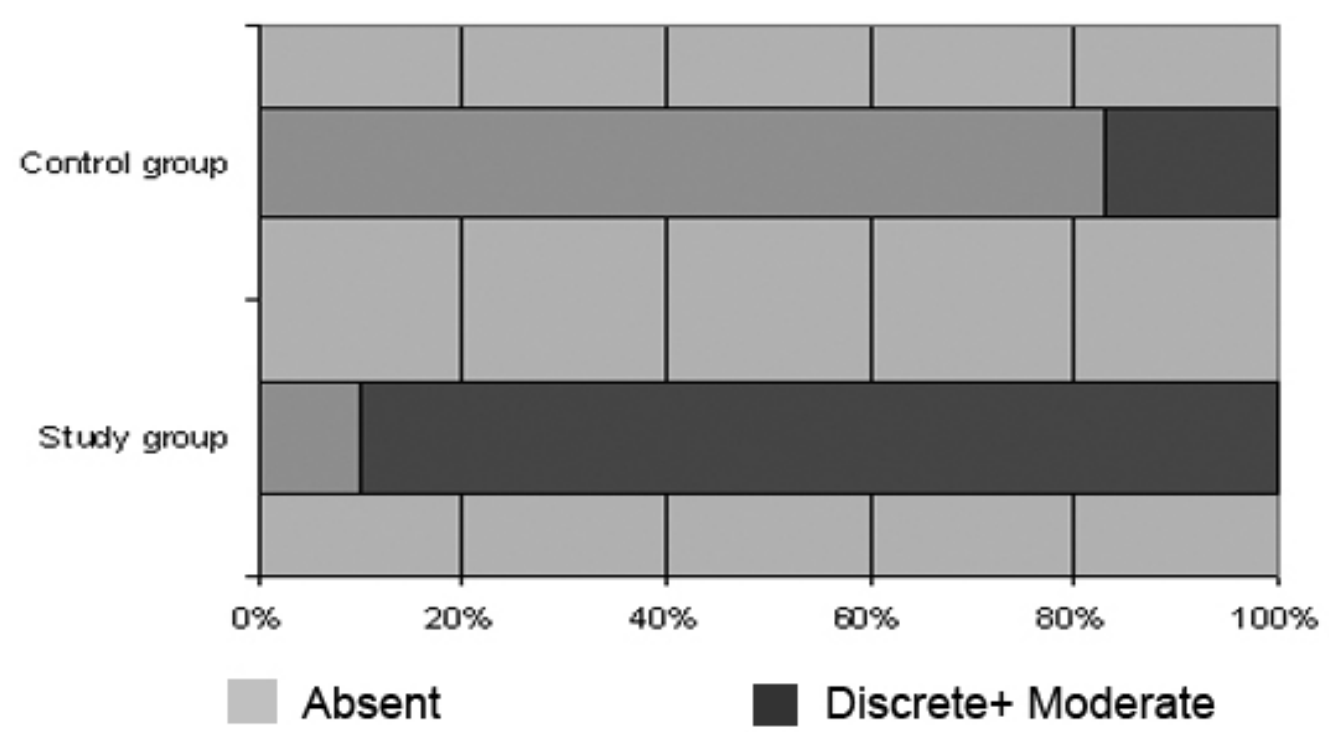

FIGURE 5 - Microscopic evaluation of fibrin and leukocyte proliferation at 14 days

\section{$\underline{\text { Evaluation considering Sirius-red coloration }}$}

The evaluation of the area showed the predominance of collagen in the Control Group compared to the Study Group in all evaluated phases, standing out the $1 \times 1$ evaluation on the 7 th day, $3 \times 3$ on the 14 th and 21 st days, with $\mathrm{P}<0,05$ (Figure 6).

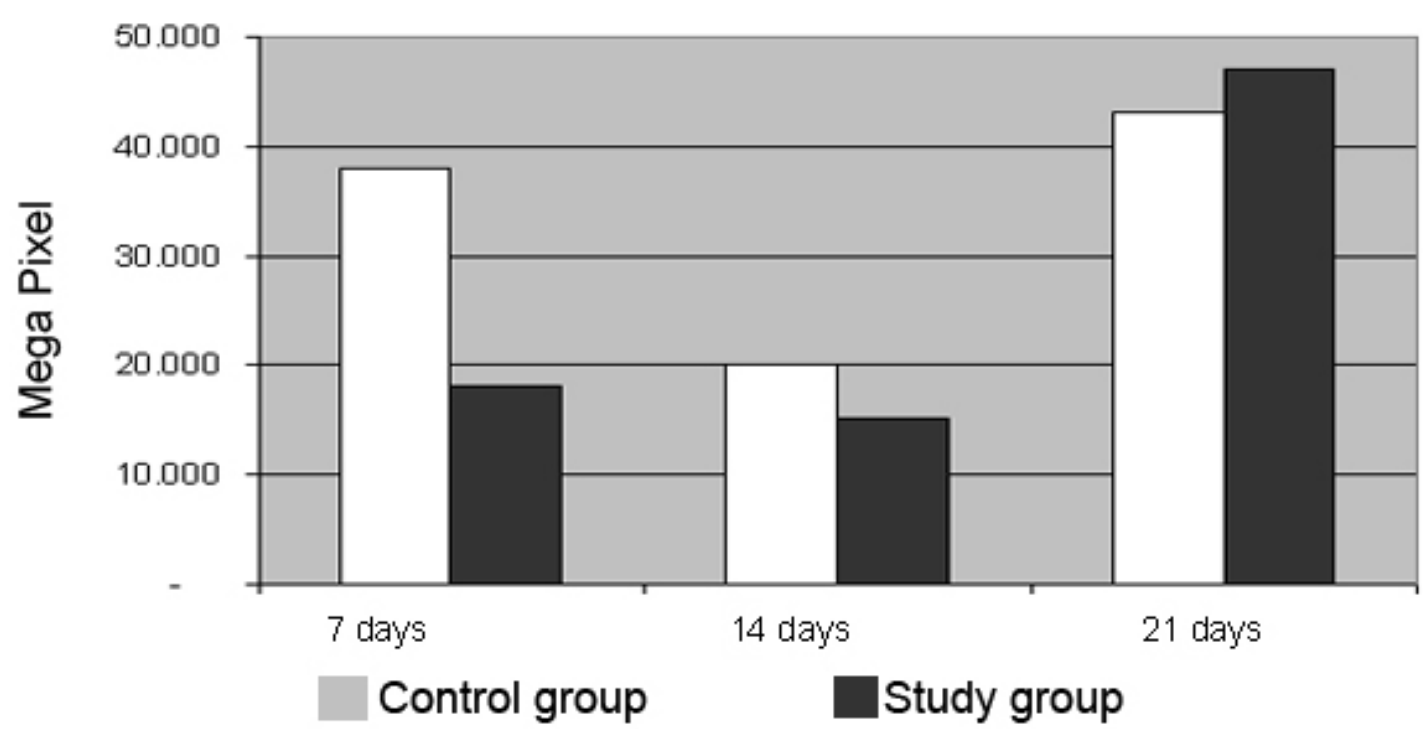

FIGURE 6 - Evaluation of the area variable with Sirius-red coloration 
The evaluation of the density variable indicated that there was a statistically significant difference between the groups at the 14 th day in the $1 \times 1$ evaluation and on the 21 st day in the $3 \times 3$ evaluation (Table 1).

TABLE 1 - Evaluation of the density variable using the Image Pro Plus (Sirius-red)

\begin{tabular}{|c|c|c|c|c|c|c|c|c|}
\hline Period & Density & Group & Average & Median & Minimum & Maximum & SD & P* value \\
\hline \multirow[t]{4}{*}{$7^{\text {th }}$ day } & \multirow{2}{*}{$3 \times 3$} & Control & 0,220 & 0,219 & 0,182 & 0,258 & 0,026 & \multirow{2}{*}{0,625} \\
\hline & & Study & 0,225 & 0,216 & 0,199 & 0,259 & 0,021 & \\
\hline & \multirow{2}{*}{$1 \times 1$} & Control & 0,272 & 0,264 & 0,216 & 0,360 & 0,049 & \multirow{2}{*}{0,680} \\
\hline & & Study & 0,264 & 0,253 & 0,192 & 0,326 & 0,047 & \\
\hline \multirow[t]{4}{*}{$14^{\text {th }}$ day } & \multirow{2}{*}{$3 \times 3$} & Control & 0,209 & 0,224 & 0,164 & 0,246 & 0,029 & \multirow{2}{*}{0,034} \\
\hline & & Study & 0,184 & 0,186 & 0,159 & 0,217 & 0,019 & \\
\hline & \multirow{2}{*}{$1 \times 1$} & Control & 0,362 & 0,359 & 0,260 & 0,485 & 0,069 & \multirow{2}{*}{0,161} \\
\hline & & Study & 0,326 & 0,313 & 0,256 & 0,434 & 0,061 & \\
\hline \multirow[t]{4}{*}{$21^{\text {st }}$ day } & \multirow{2}{*}{$3 \times 3$} & Control & 0,237 & 0,236 & 0,161 & 0,321 & 0,057 & \multirow{2}{*}{0,760} \\
\hline & & Study & 0,243 & 0,266 & 0,158 & 0,306 & 0,054 & \\
\hline & \multirow{2}{*}{$1 \times 1$} & Control & 0,280 & 0,281 & 0,219 & 0,351 & 0,049 & \multirow{2}{*}{0,020} \\
\hline & & Study & 0,325 & 0,322 & 0,276 & 0,413 & 0,044 & \\
\hline
\end{tabular}

(*) Student's t Test for independent samples $P<0,05$

As to the evaluation of the relation collagen I and III, the predominance of collagen III was found in both groups at the 7 th day evaluation. At the 14 th and 21 st days, collagen I predominated in both groups. However, on the 21 st day it was noticed that the ratio collagen I: III was higher in the Control Group when compared to the Study Group. This information was statistically significant $(\mathrm{P}=0,007)$ (Table 2 ).

TABLE 2 - Collagen I and II quantification using the Image Pro Plus (Sirius-red)

\begin{tabular}{|c|c|c|c|c|c|c|c|c|}
\hline Period & Collagen & Group & Average & Median & Minimum & Maximum & SD & $\mathrm{P}^{*}$ value \\
\hline \multirow[t]{4}{*}{$7^{\text {th }}$ day } & \multirow{2}{*}{ I } & Control & 27,91 & 26,66 & 14,98 & 43,16 & 10,16 & \multirow{2}{*}{0,548} \\
\hline & & Study & 25,96 & 26,71 & 17,98 & 31,63 & 5,61 & \\
\hline & \multirow{2}{*}{ III } & Control & 72,09 & 73,34 & 56,84 & 85,02 & 10,16 & \multirow{2}{*}{0,548} \\
\hline & & Study & 74,04 & 73,29 & 68,37 & 82,02 & 5,61 & \\
\hline \multirow[t]{4}{*}{$14^{\text {th }}$ day } & \multirow{2}{*}{ I } & Control & 60,72 & 61,85 & 47,50 & 73,34 & 9,25 & \multirow{2}{*}{0,550} \\
\hline & & Study & 58,77 & 59,74 & 51,86 & 66,98 & 5,34 & \\
\hline & \multirow{2}{*}{ III } & Control & 39,28 & 38,15 & 26,66 & 52,50 & 9,25 & \multirow{2}{*}{0,550} \\
\hline & & Study & 41,23 & 40,26 & 33,02 & 48,14 & 5,34 & \\
\hline \multirow[t]{4}{*}{$21^{\text {st }}$ day } & \multirow{2}{*}{ I } & Control & 64,89 & 61,99 & 47,60 & 84,62 & 11,40 & \multirow{2}{*}{0,007} \\
\hline & & Study & 54,65 & 56,11 & 42,57 & 62,40 & 6,77 & \\
\hline & \multirow{2}{*}{ III } & Control & 35,11 & 38,01 & 15,38 & 52,40 & 11,40 & \multirow{2}{*}{0,007} \\
\hline & & Study & 45,35 & 43,89 & 37,60 & 57,43 & 6,77 & \\
\hline
\end{tabular}

$(*)$ Student's t test for independent samples $P<0,05$

\section{Discussion}

Hypothyroidism affects people over 60 and influences protein synthesis ${ }^{14}$. The delay in the cicatricial process due to hypothyroidism has been described since 1967 by Kiviriko ${ }^{15}$ and
Kowalewsk and Yong ${ }^{16}$ who demonstrated that hypothyroidism decreases collagen synthesis and interfere with its metabolism. From then on, there has been a great interest in the study of the influence of hypothyroidism in the cicatricial process and other studies confirm its existence ${ }^{4,7}$. 
Because this work aims at evaluating the cicatricial process due to hormonal influence, we chose male animals in order to exempt a possible action of feminine hormones in the results.

The literature registers descriptions of different methods to induce hypothyroidism in rats and, among them, the anti-thyroid drugs, either by irradiation or surgery. In the present study, we chose the surgical method to treat the animals in the study group because the animals presented an efficient and homogeneous condition of hypothyroidism, avoiding collateral effects of either the anti-thyroid drugs or of irradiation.

A period of ten weeks (time considered by most studies as effective to stop the effects of hormone action at the surgical site) was observed in order to certify the hypothyroidism condition ${ }^{18,19}$. Other authors ${ }^{20}$ mention, among the main complications of thyroidectomy, the infection of the surgical wound, hemorrhage, the lesion of the laryngeal nerve and 20\% transitory hypocalcaemia and $2 \%$ permanent hypocalcaemia. This may be due to the occurrence of unintentional lesion or surgical ablation of the parathyroid glands, causing hypoparathyroidism and thyrotoxic storm.

This possibility motivated calcium reposition in the animals subjected to thyroidectomy and a subsequent calcium laboratorial dosage in the sample.

Chlorhexidine gluconate was used in the antisepsis because it does not interfere with thyroid metabolism ${ }^{21}$.

Patients with severe hypothyroidism present chronic peripheral vasoconstriction. This way, ketamine chloridrate was added to the process of anesthesia because it provides a positive inotropic effect, discretely elevates blood pressure and avoids some undesired effects of hypotention, such as the decrease of tissue perfusion that would hinder cicatrization.

For tracheal opening, Manna's ${ }^{22}$ experimental model confirmed by Mendez-Picon et al. ${ }^{23}$ was used. They described a microsurgical model of tracheotomy in adult rats in order to study three types of tracheal opening. They concluded that a transversal incision presented less morphological alterations when compared either with the longitudinal section or the excision of a segment.

As to the tracheal suture, a large bibliography on the subject was consulted, starting with Grillo ${ }^{24}$ that considered Vicryl ${ }^{\circledR}$ thread appropriate to tracheal sutures. Recently, Trimbos ${ }^{25}$ presented similar results comparing Vicryl ${ }^{\circledR}$ and Monocryl ${ }^{\circledR 2}{ }^{26}$ threads.

Many works have studied the effectiveness of many threads in rat tracheal anastomosis. Monocryl ${ }^{\circledR}$ presented the best results due to its adequate initial resistance, relatively quicker absorption, avoiding a longer inflammatory reaction ${ }^{25,26}$. Our choice of Monocryl ${ }^{\circledR}$ to perform tracheal sutures was based on these observations.

Although many works such as those of Moltke ${ }^{27}$ and Simões $^{28}$ do not confirm hyperthyroidism, we chose laboratorial confirmation of the values of thyroid stimulating hormone (TSH) and total thyroxine (T4), according to McIntosh ${ }^{18}$, Natori ${ }^{28}$ and Redei's ${ }^{29}$ works.

Laboratorial evaluation confirmed hyperthyroidism in all animals of the study group. This was coincident with other analyses mentioned in the literature.

Following Taubenhaus and Amromin's ${ }^{30}$ procedure, after thyroidectomy we opted for prophylactic calcium reposition in the animals. The quoted author added this metabolite to the animals' food but, because they refused to eat, perhaps due to its characteristic smell, we decided to add $2 \%$ calcium lactate pentahydrate to the animals' water and good acceptability was confirmed $\left(\right.$ Redei $\left.{ }^{29}\right)$. The analysis of ionic calcium levels confirmed that the reposition was sufficient because calcium values varied between 0,86 and $1,02 \mathrm{mmol} / \mathrm{L}$ in the study group and 0,94 and $1,15 \mathrm{~mm} 01 / \mathrm{L}$ in the control group, showing that there was not significant statistic difference between the groups.

The macroscopic evaluation of the suture area showed that two animals of the study group presented a small abscess at the 14 th and 21 st days after the tracheal procedure with no statistical significance in relation to the control group. This analysis also showed the presence of suture blockade in the study group at all times during euthanasia in relation to the control group with statistic significance. However, the animals did not present fistula formation.

The trachea is structurally formed by a mucous layer where we find the pseudostratified cylindrical ciliated epithelium and lamina propria and in the submucose a layer of smooth muscle with cartilaginous pieces and, peripherally farther, the adventitia layer.

The histological study with hematoxilin-eosine was performed using optical microscopy and aimed at the analyses of the variables: fibrin leukocytic scab, fibroblast proliferation, rim re-epithelization, foreign body reaction, and the presence of micro-abscesses. These parameters were classified according to their intensity following Simões ${ }^{14}$ precepts. A slight suppression of granulation in the cutaneous tissue has already been confirmed in hypothyroidism ${ }^{30}$. However, this study did not confirm this alteration. The microscopic analysis showed significant statistic difference between the groups only as to angio fibrin leukocyte proliferation which was longer and more intense in the study group. This demonstrates that hypothyroidism influences cicatrization, prolonging the inflammatory phase.

The Sirius-red histological study centered in the collagen area and density and in the quantity of types I and Ill collagen, used a microscope with polarized lens. According to Shimizu ${ }^{31}$, animals presenting hypothyroidism presented lesser connective tissue fibers than their healthy counterparts. During the proliferative phase, fibroblasts increased, with the predomination of the new collagen synthesis. The granulation tissue presented types I and III collagen; however, type I is the most abundant component. Mature dermis has $80 \%$ type I collagen and $20 \%$ type III (Zhang ${ }^{32}$ ). Tissue resistance and integrity result from the power established among the collagenous fibers and they depend on their size and structure. Resistance depends more on type I collagen, formed by stronger fibers than on collagen III ${ }^{33}$. Types IV and V fibers do not augment mechanical resistance to traction.

Macroscopic and microscopic analyses with hematoxilin-eosine and Sirius-red did not permit a thorough evaluation of the tracheal scar. This way, the tests were complementary as to morphological and functional aspects of cicatrization, estimating not only the quality but also the resolution of the lesion.

\section{Conclusion}

Hypothyroidism influences the process of tracheal cicatrization, prolonging the inflammatory phase, reducing collagen and delaying its maturation and organization. 


\section{References}

1. White VA, Kumagai LF. Preoperative endocrine and metabolic considerations. Med Clin North Am. 1979;63(6):1321-34.

2. Broughton G 2nd, Janis JE, Attinger CE. Wound healing: an overview. Plast Reconstr Surg. 2006;117(7 Suppl):1e-S-32e-S.

3. Rocha JCT. Terapia laser, cicatrização tecidual e angiogênese. RBPS. 2004;17(1):44-8.

4. Alexander MV, Zajtchuk JT, Henderson RL. Hypothyroidism and wound healing: occurrence after head and neck radiation and surgery. Arch Otolaryngol. 1982;108(5):289-91.

5. Cannon CR. Hypothyroidism in head and neck cancer patients: experimental and clinical observations. Laryngoscope. 1994;104(11 Pt 2 Suppl 66):1-21.

6. Brent GA. The molecular basis of thyroid hormone action. N Engl J Med. 1994;331(13):847-53.

7. Farling PA. Thyroid disease. Br J Anaesth. 2000;85(1):15-28.

8. Ladenson PW, Singer PA, Ain KB, Bagchi N, Bigos ST, Levy EG, Smith SA, Daniels GH, Cohen HD. American Thyroid Association guidelines for detection of thyroid dysfunction. Arch Intern Med. 2000;160(11):1573-5. 9. Natori J, Shimizu K, Nagahama M, Tanaka S. The influence of hypothyroidism on wound healing. An experimental study. Nippon Ika Daigaku Zasshi. 1999;66(3):176-80.

10. Sterling K. Thyroid hormone action at the cell level. N Engl J Med. 1979;300(3):117-23.

11. Erdogan M, Ilhan YS, Akkus MA, Caboglu SA, Ozercan I, Ilhan N, Yaman M. Effects of L-thyroxine and zinc therapy on wound healing in hypothyroid rats. Acta Chir Belg. 1999;99(2):72-7.

12. Goldenberg D, Ari EG, Golz A, Danino J, Netzer A, Joachims HZ. Tracheotomy complications: a retrospective study of 1130 cases. Otolaryngol Head Neck Surg. 2000;123(4):495-500.

13. Montovani JC, Nakajima V. Alterações epiteliais e cartilaginosas em cirurgia traqueal: estudo experimental em cobaias. Rev Bras Otorrinolaringol. 2003;69(2):159-64.

14. Simões MLPB, Ioshii SO, Borsato KS, Zimmermann E. O processo de cicatrização influenciado pelo hipotireoidismo e pelo envelhecimento: estudo da cicatrização da parede abdominal, em ratos. Acta Cir Bras. 2005;20(Suppl1):120-8.

15. Kivirikko KI, Laitinen O, Aer J, Halme J. Metabolism of collagen in experimental hyperthyroidism and hypothyroidism in the rat. Endocrinology. 1967;80(6):1051-61.

16. Kowalewski K, Yong S. Hydroxyproline in healing dermal wounds of normal and hypothyroid rats. Acta Endocrinol (Copenh). 1967;54(1):1-7.

17. Talmi YP, Finkelstein Y, Zohar Y. Pharyngeal fistulas in postoperative hypothyroid patients. Ann Otol Rhinol Laryngol. 1989;98(4 Pt 1):267-8.
18. McIntosh LM, Pernitsky AN, Anderson JE. The effects of altered metabolism (hypothyroidism) on muscle repair in the $\mathrm{mdx}$ dystrophic mouse. Muscle Nerve. 1994;17(4):444-53.

19. Frühbeck G, Cavallé C, Aragón AM, Muguerza B, Tosar A, Santidrián S. Effect of thyroxine on the rate of collagen breakdown in young thyroidectomized male rats. Rev Esp Fisiol. 1994;50(2):127-8.

20. Vanderpump MP, Tunbridge WM, French JM, Appleton D, Bates D, Clark F, Grimley Evans J, Hasan DM, Rodgers H, Tunbridge F, Young ET. The incidence of thyroid disorders in the community: a twenty-year follow-up of the Whickham Survey. Clin Endocrinol (Oxf). 1995;43(1):55-68.

21. Nunes MT. Hormônios Tireoideanos: mecanismo de ação e importância biológica. Arq Bras Endocrinol Metabol. 2003;47(6):639-43.

22. Manna MCB, Montero EFS, Silva MALG, Juliano Y. Tracheotomy in growing rats. Histological aspects. Acta Cir Bras. 2003;18(3):189-95.

23. Mendez-Picon G, Ehrlich FE, Salzberg AM. The effect of tracheostomy incisions on tracheal growth. J Pediatr Surg. 1976;11(5):681-5.

24. Grillo HC, Donahue DM, Mathisen DJ, Wain JC, Wright CD. Postintubation tracheal stenosis. Treatment and results. J Thorac Cardiovasc Surg. 1995;109(3):486-92.

25. Trimbos JB, Niggebrugge A, Trimbos R, Van Rijssel EJ. Knotting abilities of a new absorbable monofilament suture: poliglecaprone 25 (Monocryl). Eur J Surg. 1995;161(5):319-22.

26. Lazard DS, Sebagh M, Legagneux J, Vignes JL, Masquelet AC, Chabolle F. Tracheal anastomosis: monofilament absorbable suture versus monofilament non-absorbable suture. Experimental study in rats. Ann Otolaryngol Chir Cervicofac. 2004;121(3):156-60.

27. Moltke E. Wound healing influenced by thyroxine and thyrotrophic hormone; a tensiometric study. Proc Soc Exp Biol Med. 1955;88(4):596-9. 28. Natori J, Shimizu K, Nagahama M, Tanaka S. The influence of hypothyroidism on wound healing. An experimental study. Nippon Ika Daigaku Zasshi. 1999;66(3):176-80.

29. Redei EE, Solberg LC, Kluczynski JM, Pare WP. Paradoxical hormonal and behavioral responses to hypothyroid and hyperthyroid states in the Wistar-Kyoto rat. Neuropsychopharmacology. 2001;24(6):632-9. 30. Taubenhaus M, Amromin GD. The effects of the hypophysis, thyroid, sex steroids, and the adrenal cortex upon granulation tissue. J Lab Clin Med. 1950;36(1):7-18.

31. Shimizu K, Kitamura Y, Nagahama M, Chin K, Natori J, Watanabe H, Shoji T. An experimental study on wound healing in hypothyroidism. Nippon Ika Daigaku Zasshi. 1993;60(5):360-1.

32. Zhang K, Garner W, Cohen L, Rodriguez J, Phan S. Increased types I and III collagen and transforming growth factor-beta $1 \mathrm{mRNA}$ and protein in hypertrophic burn scar. J Invest Dermatol. 1995;104(5):750-4.

33. Braskén P, Renvall S, Sandberg M. Fibronectin and collagen gene expression in healing experimental colonic anastomoses. Br J Surg. 1991;78(9):1048-52.

\section{Correspondence:}

Conflict of interest: none Financial source: none

Elize Zimmermann

Al. Augusto Stellfeld, 1980

80730-150 Curitiba - PR Brazil

Phone: (55 41)3240-5488

ipem@evangelico.org.br

Received: January 21, 2009

Review: March 24, 2009

Accepted: April 28, 2009

\section{How to cite this article}

Zimmermann E, Ribas-Filho JM, Malafaia O, Ribas CAPM, Nassif PAN, Stieven Filho E, Przysiezny PE. Tracheal suture in rats with hypothyroidism. Wound healing study. Acta Cir Bras. [serial on the Internet] 2009 July-Aug;24(4).

Available from URL: http://www.scielo.br/acb 